\title{
REPRESENTASI BUDAYA DALAM KOMIK STRIP PANJI KOMING
}

\author{
Ismail \\ Kajian Budaya dan Media \\ Fakultas Usuluddin IAIN Sulthan Thaha Saifuddin Jambi \\ Email: Ismail.albanjari@gmail.com Telp.081219698947 \\ Heru Nugroho \\ Fakultas Ilmu Sosial dan Politik Universitas Gadjah Mada \\ G.R. Lono Lastoro Simatupang \\ Jurusan Antropologi Fakultas Ilmu Budaya Universitas Gadjah Mada
}

\begin{abstract}
Abstrak: Representasi kebudayaan Jawa dapat didentifikasi dari beberapa adegan misalnya, gerak fisik, tutur kata, pakaian yang digunakan berikut aksesorisnya. Komik Strip "Panji Koming" memunculkan Prinsip-prinsip dan etika ke-Jawa-an dalam beberapa adegan pada tiap edisinya. Masyarakat Jawa adalah masyarakat yang menjunjung tinggi budaya unggahungguh atau tatakrama. Karena itu penghormatan menjadi kunci untuk dapat hidup secara harmonis dalam tatanan masyarakat secara keseluruhan. Penghormatan itu ditunjukkan dalam berbagai cara: sikap badan, tangan, nada suara, istilah penyapa, dan diatas segala-galanya, termasuk tataran bahasa yang dipergunakan. Adanya stereorip pada perempuan Jawa dipandang jelas, karena adanya representasi sederhana yang mereduksi perempuan menjadi serangkaian karekteristik yang dibesar-besarkan dan biasanya berkonotasi negatif. Jadi stereotip mereduksi, mendasarkan, mengalamiahkan dan mematok perbedaan.
\end{abstract}

\section{Kata Kunci: tata krama, perempuan Jawa, keluarga}

\begin{abstract}
The representation of Javanese culture can be identified into some acts, for examples phisical movements, speech acts, costume with its accessories. Comic strip Panji Koming presents the principles and Javanese ethics and values in some actions on its each edition. Javanese society is a society which highly upholds unggah-ungguh tradition or tatakrama. Therefore, giving respect to others is the key to live harmoniously in society's structure as a whole. Giving respect is shown in some various ways: body's attitude, hands, pitch, address system, and everything including formality level of language. The stereotype of Javanese women is reduced to simple representation of women as has always been connotatively negative coined. The stereotype applied to women is the product of the acts of reducing, giving standart, naturalizing, and creating difference.
\end{abstract}

\section{Keywords : tata krama, Javanese women, family}




\section{Pendahuluan}

Dalam kehidupan sehari-hari, biasanya ketika membaca surat kabar atau majalah, sering ditemui kilasan-kilasan cerita, baik yang bersifat imajinasi atau pun gambaran, dari realitas sosial yang disajikan dalam bentuk gambar dan terkadang dibubuhi balon teks. Ketika membaca cerita itu, biasanya kita menemukan lelucon segar, bahkan seringkali membuat kita menertawakan diri sendiri dan lingkungan sosial kita. Hal ini menurut Burton, disebabkan oleh fungsi media yang telah berkembang, salah satunya adalah fungsi kultural. Dalam menjalankan fungsi kultural, media menghasilkan materi yang mencerminkan budaya dan menjadi bagian dari budaya tersebut. Secara praktis dapat dikemukakan; pertama, materi ini mempertahankan dan mentransmisikan budaya kita dan menghasilkan kontinuitas bagi budaya tersebut; kedua, materi ini mengembangkan budaya massa dengan mengorbankan keanekaragaman subkultur; dan ketiga, materi ini dapat mempertahankan status quo dalam pengertian kultural, tetapi juga dapat mendorong perubahan dan pertumbuhan (Burton, 1988: 88).

Ungkapan sosial yang disajikan dalam bentuk gambar, merupakan bentuk visualisasi dari kreatifitas komunikasi desain komunikasi visual yang berhadapan dengan sejumlah alat, teknik, bahan, dan keterampilan. Ungkapan yang baik, akan lebih bernilai apabila didukung dengan teknik yang baik, dan ditunjang kepiawaian seseorang dalam mewujudkannya. Seperangkat alat yang dimanfaatkan oleh desainer komunikasi visual, antara lain adalah aspek visual yang meliputi bentuk ilustrasi, layout, warna serta aspek verbal yang terdiri dari teks dan tipografi (Jewler dan Drewniany, 2001: 57).

Komik, kartun dan karikatur adalah ekspresi ungkapan memalui gambar sebagai salah satu bentuk komunikasi
visual.Sebagai salah satu bentuk komunikasi grafis. Komik, kartun dan karikatur merupakan suatu gambar interpretatif yang menggunakan simbolsimbol untuk menyampaikan suatu pesan secara cepat dan ringkas, atau sesuatu sikap terhadap orang, situasi, atau kejadiankejadian tertentu. Komik, kartun dan karikatur biasanya hanya mengungkap esensi pesan yang harus disampaikan dan menuangkannya ke dalam gambar sederhana, tanpa detail, dengan menggunakan simbol-simbol, serta karakter yang mudah di kenal dan dimengerti secara cepat (Fauziah, 2011).

Berkaitan dengan hal tersebut, ada tiga istilah yang sering dipahami secara keliru, yakni komik, kartun, atau karikatur. Ketiga istilah ini memang seringkali dipertukarkan, bahkan oleh para pelaku media sendiri. Padahal sesungguhnya masing-masing memiliki karakter dan ciri khas tersendiri. Pertama, komik secara umum adalah cerita bergambar dalam majalah, surat kabar, atau dapat pula berbentuk buku, yang pada umumnya mudah dicerna dan lucu. Pengertian tersebut adalah benar, namun pengertian ini mejadi kurang tepat bagi komik-komik yang menampilkan bacaan atau cerita-cerita serius. Tujuan utama komik adalah sebagai hiburan dalam bentuk bacaan ringan, meski cerita yang disajikan beberapa diantaranya relatif panjang, namun tidak selalu terkait dengan pesan-pesan moral tertentu. Namun secara umum, komik terdiri dari teks dan gambar dan hal ini menjadi ciri utama komik dibanding media serupa lainnya (Setiawan, 2002:22)

Berdasarkan jenisnya, komik dapat dikelompokkan menjadi dua, yaitu komik strip (comic-strips) dan komik buku (comicbooks). Komik strip (comic-strips) atau strip merupakan komik bersambung yang dimuat dimuat pada surat kabar. Adapun komik buku (comic-books) adalah kumpulan cerita bergambar yang terdiri dari 
satu atau lebih judul dan tema cerita, yang di Indonesia disebut komik atau buku komik. Pada perkembangannya kini komik, menurut Bersihar Lubis, mengalami beberapa modifikasi mulai dari format, muatan isi, teknis pembuatan, hingga strategi pemasarannya. Beberapa komik diterbitkan seiring dengan peluncuran animasi layar lebarnya, seperti yang dilakukan oleh Walt Disney dangan Mickey Mouse, Beauty and The Beast, Lion King's, Mulan, dan lain-lain (Sobur, 2009:137).

Kedua, kartun adalah sebuah gambar lelucon yang muncul di media massa yang biasanya hanya berisi humor semata tanpa membawa kritik sosial apapun. Namun ada juga yang mengungkapkan masalah sesaat secara ringkas namun tajam dan humoris sehingga tidak jarang membuat pembaca tersenyum, dan ketiga, karikatur adalah deformasi berlebihan atas wajah seseorang, biasanya orang terkenal, dengan mempercantiknya dengan penggambaran ciri khas lahiriahnya dan biasanya bertujuan untuk mengolok-olok (Setiawan, 2002: 22).

Dari ketiga definisi di atas sesungguhnya dapat diidentifikasi masingmasing perbedaan khusus. Namun demikian, persamaan umum dari ketiga media visual tadi adalah sama-sama karya seni visual yang mudah dicerna. Pada tulisan ini yang akan dijadikan objek penelitian adalah komik. Menurut Setiawan, komik itu sendiri sesungguhnya sering disajikan dengan cara yang beragam, ada yang berbentuk buku dan ada pula yang berbentuk potongan-potongan atau lazim disebut dengan komik strip (Setiawan, 2002: 23).

\section{Pembahasan}

\section{Panji Koming Itu Jawa}

Dalam konteks Indonesia, salah satu komik yang terbilang "senior" dan masih eksis hingga saat ini adalah Komik Strip Panji Koming karya Dwi Koendoro yang terbit setiap hari Minggu di Surat kabar Kompas. Secara umum, lakon Panji Koming mengambil setting Kerajaan Majapahit diambang kehancurannya yang disebut Dwi Koendoro sebagai Zaman Kala Bendhu, zaman kekacauan. Selain Panji Koming, beberapa tokoh utama dalam komik ini antara lain; Pailul, Ni Woro Ciblon, Ni Dyah Gembili, Empu Randubanthal, dan Bhre Denmas Ariakendor. Secara semiotis, masingmasing tokoh ini merupakan representasi dari suatu realitas sosial. Itulah sebabnya, lelucon yang disajikan seringkali banyak berkaitan dengan suasana kehidupan sosialpolitik di Indonesia (Koendoro, 1998: xii).

Meski mengambil setting Majapahit, banyak pihak termasuk budayawan Umar Khayam melihat bahwa "Panji Koming" adalah Jawa. Artinya, simbol-simbol yang digunakan dalam adegan komik tersebut disandarkan pada kebudayaan Jawa. Alhasil, karakter-karakter atau tokoh-tokoh yang muncul-pun merepresentasikan masyarakat dan kebudayaan Jawa, meski tidak secara eksplisit.

Menurut Roqib, representasi kebudayaan Jawa itu dapat didentifikasi dari beberapa adegan misalnya, gerak fisik, tutur kata, pakaian yang digunakan berikut aksesorisnya. Komik Strip "Panji Koming" memunculkan Prinsip-prinsip dan etika keJawa-an dalam beberapa adegan pada tiap edisinya. Oleh karena itu, identifikasi Panji Koming sebagai komik Jawa mungkin tidak terlalu berlebihan. Hal ini kemudian berimbas pada wilayah lain. Misalnya representasi kelas sosial, gender, sampai pada persoalan-persoalan krusial seperti politik. Oleh karena itu, dalam hal ini perlu diketahui identitas masyarakat dan budaya Jawa yang sesungguhnya untuk memperkuat asumsi tadi (Roqib, 2007: 7). 


\section{Tata Krama dalam Budaya Jawa}

Masyarakat Jawa adalah masyarakat yang menjunjung tinggi budaya unggahungguh atau tatakrama. Tatakrama yang detail dalam segala perilaku. Ada sebutan mikul duwur mendem jero (menganggkat tinggi-tinggi dan mengubur dalam-dalam) yang digunakan untuk memberikan pesan agar orang berkenan menghormati orang tua dan pimpinan, ojo ngono ora ilok (jangan begitu tidak baik), tidak baik dinyatakan dengan ora ilok, menunjukkan bahwa ada kesan sakral dan masih banyak istilah lain yang digunakan orang Jawa (Sugiarto, 2010).

Memperbincangkan budaya Jawa adalah juga memperbincangkan masyarakat, etika, perilaku, norma-norma dan segala sesuatu yang terkait dengan masyarakat Jawa baik secara langsung ataupun tidak. Menurut Geertz dalam kosmologis budaya Jawa, penghormatan menjadi kunci untuk dapat hidup secara harmonis dalam tatanan masyarakat secara keseluruhan. Penghormatan itu ditunjukkan dalam berbagai cara: sikap badan, tangan, nada suara, istilah penyapa, dan diatas segalagalanya, termasuk tataran bahasa yang dipergunakan. Terdapat dua tataran besar dalam bahasa: hormat (krama), dan akrab (ngoko). Pada gilirannya, tataran ini dapat diubah dengan menambahkan dua tataran lagi, sangat hormat (krama inggil) dan akrab namun hormat (ngoko madya) (Geertz, 1983:24).

Menurut Abdullah, semua norma ini telah dipelajari sejak kecil oleh "Orang Jawa" dan menjadi pola asuhan pada keluarga Jawa. Oleh karena itu, istilah "keluarga Jawa" dalam pandangan Abdullah bukan hanya menunjukkan suatu unit interaksi, tetapi juga sebuah sistem dimana keseluruhan tatanan sosial bermuara, menjadi sumber bagi penataan sosial yang sangat luas melebihi batas-batas keluarga itu sendiri (Abdullah, 2009:153). Hal senada juga dituturkan oleh Geertz, bahwa semenjak bayi masih digendong kesanakemari dan belum mengerti sepenuhnya tentang tingkah laku serta kata-kata orang yang ada di sekitarnya, bayi sudah mulai diajari dengan sopan santun. Segera sesudah dia mulai bisa memegang makanan di tangannya dan menerima makanan yang diulurkan kepadanya, dia sudah diajari secara teratur bahwa hanya tangan kananlah yang layak. Setiap ia mengulurkan tangan kiri untuk mengambil sesuatu yang diberikan kepadanya, ibunya langsung menarik tangan kanan anak itu untuk menerimanya. Gerak spontan anak itu sendiri diabaikan, digantikan dengan gerak yang dilakukan oleh ibunya tanpa kehendak sukarela anak itu sendiri (Geertz, 1983:106).

Cara pendidikan serupa dengan mendorong dan menarik pada pola gerakan yang sederhana dalam hal menanamkan bentuk basa-basi. Tentu saja anak-anak belajar berkomunikasi dengan ibunya dalam bentuk ngoko yang sama seperti yang dipergunakan ibunya kepada dirinya, tapi sejak awal belajar terdapat upaya yang disengaja agar membiasakannya menggunakan kalimat-kalimat bersopan santun kepada orang lain. Oleh karena itu, kata pertama yang dikenali anak biasanya adalah, nyuwun yang berarti meminta dengan hormat. Pendidikan berbasa-basi ini sangat diutamakan di kalangan priyayikelas bangsawan-sehingga anak seorang priyayi biasanya telah mempraktikkan basabasi ini dengan sangat baik sejak ia kecil (Geertz, 1983: 107-108).

Masyarakat Jawa memang sangat mengutamakan etika dan norma yang seringkali dikaitkan dengan konsekuensi yang akan diterimanya di kemudian hari. Berkenaan dengan ini, Franz-Magnis Suseno mengungkapkan, bahwa etika merupakan ilmu atau refleksi sistematik mengenai pendapat-pendapat, norma-norma, dan istilah-istilah moral. Dalam pengertian khusus, etika Jawa adalah norma dan penilaian yang dipergunakan oleh 
masyarakat Jawa seharusnya menjalankan kehidupannya: bagaimana ia harus membawa diri, sikap-sikap dan tindakantindakan mana yang harus dikembangkan agar hidupnya berhasil dalam arti memperoleh kenikmatan sebanyakbanyaknya, pengakuan oleh masyarakat, pemenuhan kehendak Tuhan, kebahagiaan, kesesuaian dengan tuntutan-tuntutan kewajiban mutlak dan sebagainya. Secara sosial, orang Jawa membedakan dua golongan sosial: (1) wong cilik (orang kecil), terdiri dari sebagian massa petani dan mereka yang berpendapatan rendah di kota, dan (2) kaum priyayi, yakni pegawai dan intelektual (Ismawati, 2005: 45-46). Stratifikasi atau kelas sosial ini banyak berimplikasi pada pola perilaku, cara berpikir dan bertindak dalam konteks kehidupan sosial yang lebih luas.

\section{Steriotipe Perempuan Jawa}

Sebagaimana telah dikemukakan di atas, bahwa keluarga dalam masyarakat Jawa merupakan sistem yang membentuk perilaku seorang anak. Biasanya hal ini dikait-kaitkan dengan peran perempuan dalam keluarga. Inilah yang seringkali menjadi isu sensitif untuk diperbincangkan karena pada umumnya masyarakat Jawa, tidak hanya kaum laki-laki, tetapi juga perempuan itu sendiri beranggapan bahwa perempuan yang baik adalah yang tunduk dan patuh pada peran-peran yang telah ada sebelumnya, dengan kata lain peran yang telah dikonstruksi. Dalam hal ini bias gender mendapat tempat untuk diperbincangkan. Terkait dengan perbincangan mengenai bias gender, Fakih menyatakan, bahwa sesungguhnya sejarah perbedaan gender (gender differences) antara manusia jenis laki-laki dan perempuan terjadi melalui proses yang sangat panjang. Oleh karena itu, terbentuknya perbedaan-perbedaan gender dikarenakan oleh banyak hal, diantaranya; dibentuk, disosialisasikan, diperkuat, bahkan dikonstruksi secara sosial atau kultural, melalui ajaran keagamaan maupun negara. Melalui proses panjang, sosialisasi gender tersebut akhirnya dianggap sebagai ketentuan Tuhan, seolah-olah bersifat biologis, yang tidak bisa diubah lagi, sehingga perbedaan-perbedaan gender dianggap dan dipahami sebagai kodrat lakilaki dan kodrat perempuan (Fakih, 1996: 9).

Perempuan secara langsung menunjuk kepada salah satu dari dua jenis kelamin, meskipun di dalam kehidupan sosial selalu dinilai sebagai the other sex yang sangat menentukan mode representasi sosial tentang status dan peran perempuan. Marginalisasi perempuan yang muncul kemudian menujukkan bahwa perempuan menjadi the second sex, seperti juga sering disebut sebagai "warga kelas dua" yang keberadaannya tidak begitu diperhitungkan. Dikotomi nature dan culture, misalnya telah digunakan untuk menujukkan pemisahan dan stratifikasi diantara dua jenis kelamin ini, yang satu memiliki status yang lebih rendah dari yang lainnya. Perempuan yang mewakili sifat alam (nature) harus ditundukkan agar mereka lebih berbudaya. Dalam berbagai bentuk diskursus tampak bahwa peran perempuan sebagai istri memang sangat dominan, tidak hanya seperti didefinisikan oleh laki-laki, tetapi juga oleh perempuan sendiri. Ideologi familiarisme yang direproduksi dalam berbagai bentuk diskursus, telah menjadikan kekuatan penting dalam menyadarkan (atau menegaskan pada) perempuan tentang peran domestik mereka (Abdullah, 2006: 3-7).

Pada kenyataannya, perempuan Jawa selain sebagai individu (manusia), juga sebagai istri dan ibu bagi anakanaknya. Dalam konteks budaya Jawa, perempuan sebagai istri memiliki tugas dan persyaratan fisik-psikis dan sosial yang amat berat. Begitu juga, bahwaPerempuan dalam budaya jawa diibaratkan sebagai bunga. Ia indah dipandang dan selalu 
memancarkan bau harum mewangi. Ia adalah ratu yang bertahta dengan agung di dalam rumah tangganya. Serat Yadyasusila menerangkan tiga sifat wanita sebagai ratu rumah tangga yang baik, yakni merak ati, gemati, dan luluh. Merak ati dimaknai pandai menjaga kecantikan lahir dan batin, pandai bertutur sapa dengan santun, pandai mengatur pakaian yang pantas, murah senyum, luwes gerak-geriknya dan lumampah anut wirama, bertindak sesuai irama. Gemati artinya menunaikan kewajiban sebagai istri dengan sebaikbaiknya. Sebagai istri, seorang perempuan harus bertugas sebagai perawat rumah tangga dan mengatur keuangan sebaikbaiknya. Ia bertugas mendidik anak dengan naulri keibuannya yang terasah. Sedangkan luluh artinya penyabar, tidak keras kepala, menerima segala masalah dengan hati lapang (Roqib, 2007: 70-71).

Menurut Liliweri, hal ini pada akhirnya akan berujung pada identitas perempuan Jawa. Ia cenderung menjadi hukum yang pasti yang tidak boleh dilanggar. Padahal, identitas selalu berada dalam gerak, artinya identitas itu bersifat dinamis dan tidak pernah stabil. Setiap orang berubah sepanjang waktu baik secara aktif maupun pasif. Identitas tidak selalu tetap, tetapi prosesnya sering berubah-ubah. Oleh karena itu, kita selalu berusaha mendekati, membentuk dan bahkan menerima transformasi perubahan itu (Liliweri, 2003: 81-82).

Sehubungan dengan hal di atas, Komik Panji Koming dengan latar Majapahit yang identik dengan masyarakat Jawa, pada akhirnya harus merepresentasikan perempuan yang juga, merupakan perempuan Jawa dengan berbagai macam identitas yang telah diungkapkan di atas. Perempuan Jawa direpresentasikan melalui dua tokoh yakni "Ni Woro Ciblon" dan "Ni Dyah Gembili" yang masing-masing memperlihatkan ciri identitas yang kontradiktif. Ciblon adalah perempuan berparas cantik dan cenderung manut, sementara Gembili adalah sosok perempuan yang dikarakterisasikan sebagai tokoh yang tidak menyenangkan, memiliki postur tubuh yang gembil (gembrot) dan juga kritis pada kebijakan yang tidak adil. Sepertinya, Gembili adalah tokoh yang kontra-budaya Jawa.

Berkaitan dengan perbandingan antara paras yang cantik dan jelek, kita dapat melihat analisis Baldesar Castiglione berikut:

Kecantikan adalah sesuatu yang sakral. (ia) muncul dari Tuhan dan terlihat seperti sebuah lingkaran, dimana pusat kebaikan berasal. Dan begitulah, sama seperti orang tidak dapat memiliki kecantikan tanpa kebaikan. Konsekuensinya, jiwa yang jahat jarang berdiam di dalam sebuah tubuh yang cantik dan merupakan sesuatu yang keliru jika kecantikan luar menjadi tanda sejati kebaikan batiniah...Dengan kata lain, sebagian besar kejelekan adalah kejahatan, dan kebaikan adalah cantik. Dengan kata lain, kecantikan itu menyenangkan, ramah, menarik dan wajah yang diinginkan dari kebaikan; sementara kejelekan itu gelap, tidak disetujui, tidak menyenangkan dan merupakan wajah penyesalan dari kejahatan. Dapat dikatakan, dalam beberapa hal kebaikan dan kecantikan identik, khususnya dalam tubuh manusia. Dan penyebab terbesar kecantikan fisik, menurut pendapat saya, adalah kecantikan jiwa (Synnott, 1993: 136).

Secara fisik, apa yang dikatakan Synnott adalah proses identifikasi penampilan fisik dengan karakter atau perilaku. Sayangnya, fenomena ini telah menjadi semacam general truth (kebenaran umum). Lihatlah, misalnya dalam film atau dongeng-dongeng, tokoh jahat selalu diidentikkan tidak hanya dengan sosok yang tidak menyenangkan, tetapi juga berpenampilan fisik, kurang sedap 
dipandang. Sementara tokoh protagonis selalu cantik dan mempesona (Synnott, 1993: 137).

Secara teoritik Hall menyebutkan bahwa, setidaknya ada tiga pendekatan dalam teori representasi, yakni pendekatan reflektif, intensional dan konstruktif. Pertama, pendekatan reflektif adalah ketika bahasa bekerja seperti cermin realitas. Artinya makna yang diperolehnya berasal dari realitas yang benar-benar ada di dunia nyata. Ketika seseorang mengucapkan kata "mawar", maka makna yang dikandung dalam kata "mawar" itu memang bunga mawar yang sesungguhnya. Kedua, adalah pendekatan intensional, pada tataran ini makna sebuah bahasa dikendalikan sepenuhnya oleh sang penutur, yang biasanya bertujuan untuk memasukkan makna unik dan spesifik melalui bahasa. Dengan kata lain, kata-kata harus dimaknai sesuai dengan apa yang dimaknai oleh sang penutur (the author). Kemudian ketiga adalah pendekatan konstruksionis, yang melihat makna sebagai sesuatu yang dialektis. Kita melakukan konstruksi makna atas bahasa atau kata-kata melalui sistem representasi yang digunakan, yakni konsep dan tanda. Pendekatan ini melihat bahwa kita tidak perlu dibingungkan oleh dunia material. Kalangan konstruktivis beranggapan bahwa sistem bahasa atau sistem apapun dapat kita gunakan untuk merepresentasikan konsep yang kita maksudkan (Hall, 1977: 24-27).

Representasi dipahami sebagai gambaran sesuatu yang akurat atau realita terdistorsi. Representasi tidak hanya berarti "to presentasi", "to image", atau "to depict". Representasi adalah sebuah cara dimana memaknai apa yang diberikan pada benda yang digambarkan. Konsep lama mengenai representasi ini didasarkan pada premis bahwa ada sebuah representasi yang menjelaskan perbedaan antara makna yang diberikan oleh representasi dan arti benda yang sebenarnya digambarkan. Stuart Hall berargumentasi bahwa representasi harus dipahami dari peran aktif dan kreatif orang memaknai dunia. Hall menunjukkan bahwa sebuah imaji akan mempunyai makna yang berbeda dan tidak ada garansi bahwa imaji akan berfungsi atau bekerja sebagaimana mereka dikreasi atau dicipta. Hall menyebut 'representasi sebagai konstitutif'. Representasi tidak hadir sampai setelah selesai direpresentasikan, representasi tidak terjadi setelah sebuah kejadian. Representasi adalah konstitutif dari sebuah kejadian. Representasi adalah bagian dari objek itu sendiri, ia adalah konstititif darinya. (Hall, 1997: 61)

Hall juga menjelaskan (1997:61-63) bahwa, pernyataan mengenai sirkulasi makna secara otomatis melibatkan isu kekuasaan. Siapa yang mempunyai kekuasaan, di channel yang mana, untuk mensirkulasikan makna kepada siapa. Hall memahami bahwa komunikasi selalu berhubungan dengan kekuasaan. Kelompok yang memiliki dan menggunakan kekuasaan dalam masyarakat mempengaruhi apa yang direpresentasikan melalui media. Pesan-pesan tersebut bekerja secara kompleks. Pengetahuan dan kekuasaan saling bersilangan. Isu kekuasaan tidak dapat dilepaskan dari pertanyaan representasi. Gambaran menaturalisasikan representasi. Praktik representasi itu sendiri melakukan naturalisasi representasi sampai anda tidak melihat siapa yang memproduksi mereka. Gambaran-gambaran ini telah menyembunyikan proses representasi. Sehingga tampaknya seperti itulah realita yang terjadi. Sehingga mengarah pada praktik representasi. Ada beberapa pertanyaan yang terlontar antara lain:

1) Darimana gambaran-gambaran ini datang?

2) Siapa yang memproduksi gambarangambaran tersebut?

3) Siapa yang dibungkam dalam produksi gambaran-gambaran tersebut? 


\begin{abstract}
Dengan demikian, representasi
\end{abstract} terbuka pada pengetahuan-pengetahuan baru untuk diproduksi dalam dunia, berbagai macam subyektivitas untuk dieksplor, dan dimensi baru makna yang tidak pernah menutup sistem kekuasaan yang sedang beroperasi.

Menurut Barker, representasi meliputi sejumlah pentanyaan inklusi dan eksklusi dan selalu berimbas pada soal kekuasaan, dan kekuasaan biasanya merepresentasikan suatu dominasi yang mengarah pada stereotip. Stereorip dipandang jelas, namun merupakan representasi sederhana yang mereduksi orang menjadi serangkaian karekteristik yang dibesar-besarkan dan biasanya berkonotasi negatif (Barker, 2009: 219). Senada dengan itu Dyer, menyatakan bahwa stereotip biasanya mengarah dalam eksklusi orang lain dari tatanan sosial, simbolis, dan moral, yaitu berupa tipe sosial yang diarahkan untuk dikeluarkan dari desain dan menitik beratkan kepada mereka yang dikeluarkan dari tatanan "normal" berbagai hal dan secara simultan menempatkan siapa "kita" dan siapa "mereka". Jadi stereotip mereduksi, mendasarkan, mengalamiahkan dan mematok "perbedaan (Dyer, 1977:2930).Penjelasan di atas menguatkan, bahwa Stereotip ini juga muncul dan dianalogikan pada tokoh-tokoh yang terdapat dalam komik strip "Panji Koming".

Stereotip yang sesungguhnya adalah representasi yang disederhanakan dari penampilan manusia, karekter, dan kepercayaan. Stereotip telah mapan lewat representasi bertahun-tahun dalam media serta lewat berbagai asumsi dalam percakapan sehari-hari. Stereotip merupakan distorsi dari tipe mula-mula, karena stereotip melebih-lebihkan sekaligus menyederhanakan. Stereotip memiliki kualitas dapat dikenal secara tepat, biasanya lewat berbagai rincian kunci dalam penampilan. Kedalaman stereotip biasanya ditanamkan dari berbagai pertimbangan implisit tentang karakter tersebut (pesanpesan tentang nilai secara terselubung), karena itu dalam hal ini audiens perlu selektif untuk menilai pandangan media tentang budaya (Burton, 1988:115).

Apa yang direpresentasikan lewat tipe-tipe (stereotip) juga melebihi dari sekadar pendangan tentang pelbagai kategori orang tetap tampak seperti orangorang pada umumnya, juga dapat dilihat representasi sikap-sikap terhadap tipe tersebut. Sikap-sikap tersebut dikonstruksi dengan karakteristik-kareakteristik tertentu dan dipresentasikan dengan cara tertentu. Representasi-representasi juga dikonstruksi lewat media yang digunakan. Secara prinsip, terdapat berbagai unsur dan perangkat yang mengkonstruksi tipe. Dan yang terpenting untuk disadari adalah tipe-tipe yang berkaitan dengan nilai-nilai serta atribut fisik. Ketika merepresentasikan kelompokkelompok orang, media juga sering mengatakan berbagai hal tentang budaya, dalam hal ini kelompok-kelompok orang tersebut dalam budaya atau subkultur tertentu. Dan pandangan tentang budayabudaya yang direpresentasikan tersebut, memuat pesan-pesan tentang budaya tersebut (Burton, 1988: 120-123).

\section{Penutup}

Representasi kebudayaan Jawa itu dapat didentifikasi dari beberapa adegan misalnya, gerak fisik, tutur kata, pakaian yang digunakan berikut aksesorisnya. Komik Strip "Panji Koming" memunculkan Prinsip-prinsip dan etika keJawa-an dalam beberapa adegan pada tiap edisinya. Oleh karena itu, identifikasi Panji Koming sebagai komik Jawa mungkin tidak terlalu berlebihan. Hal ini kemudian berimbas pada wilayah lain. Misalnya representasi kelas sosial, gender, sampai pada persoalan-persoalan krusial seperti politik. Oleh karena itu, dalam hal ini perlu diketahui identitas masyarakat dan budaya 
Jawa yang sesungguhnya untuk memperkuat asumsi tadi.

Masyarakat Jawa adalah masyarakat yang menjunjung tinggi budaya unggahungguh atau tatakrama. Karena itu penghormatan menjadi kunci untuk dapat hidup secara harmonis dalam tatanan masyarakat secara keseluruhan. Penghormatan itu ditunjukkan dalam berbagai cara: sikap badan, tangan, nada suara, istilah penyapa, dan diatas segalagalanya, termasuk tataran bahasa yang dipergunakan.

Semua norma ini telah dipelajari sejak kecil oleh "Orang Jawa" dan menjadi pola asuhan pada keluarga Jawa. Pendidikan semenjak bayi masih digendong kesana-kemari dan belum mengerti sepenuhnya tentang tingkah laku serta katakata orang yang ada di sekitarnya, bayi sudah mulai diajari dengan sopan santun. Oleh karena itu, kata pertama yang dikenali anak biasanya adalah, nyuwun yang berarti meminta dengan hormat. Pendidikan berbasa-basi ini sangat diutamakan di kalangan priyayi-kelas bangsawansehingga anak seorang priyayi biasanya telah mempraktikkan basa-basi ini dengan sangat baik sejak ia kecil.

Sebagaimana telah dikemukakan di atas, bahwa keluarga dalam masyarakat Jawa merupakan sistem yang membentuk perilaku seorang anak. Tidak hanya kaum laki-laki, tetapi juga perempuan itu sendiri beranggapan bahwa perempuan yang baik adalah yang tunduk dan patuh pada peranperan yang telah ada sebelumnya, dengan kata lain peran yang telah dikonstruksi.

Dalam Serat Yadyasusila menerangkan tiga sifat wanita sebagai ratu rumah tangga yang baik, yakni merak ati, gemati, dan luluh. Merak ati dimaknai pandai menjaga kecantikan lahir dan batin, pandai bertutur sapa dengan santun, pandai mengatur pakaian yang pantas, murah senyum, luwes gerak-geriknya dan lumampah anut wirama, bertindak sesuai irama. Gemati artinya menunaikan kewajiban sebagai istri dengan sebaikbaiknya. Sebagai istri, seorang perempuan harus bertugas sebagai perawat rumah tangga dan mengatur keuangan sebaikbaiknya. Ia bertugas mendidik anak dengan naulri keibuannya yang terasah. Sedangkan luluh artinya penyabar, tidak keras kepala, menerima segala masalah dengan hati lapang

Adanya Stereorip pada perempuan Jawa dipandang jelas, karena adanya representasi sederhana yang mereduksi orang "perempuan" menjadi serangkaian karekteristik yang dibesar-besarkan dan biasanya berkonotasi negatif. Jadi stereotip mereduksi, mendasarkan, mengalamiahkan dan mematok "perbedaan".Penjelasan di atas menguatkan, bahwa Stereotip ini juga muncul dan dianalogikan pada tokoh-tokoh yang terdapat dalam komik strip "Panji Koming".

\section{Daftar Pustaka}

Abdullah, I., 2009, Konstruksi dan Reproduksi Kebudayaan, cet. ke-3, Yogyakarta: Pustaka Pelajar.

Barker, C., 2009, Cultural Studies (terj. Nurhadi), Yogyakarta: Kreasi Wacana.

Burton, G., 1988, Yang Tersembunyi di Balik Media, disunting oleh Alfathri Adlin, Yogyakarta dan Bandung: Jalasutra.

Dyer, R., 1977, Gays and Film, London: British Film Institute.

Fakih, M., 1996, Analisis Gender dan Transformasi Sosial, Yogyakarta: Pustaka Pelajar.

Fauziah, A., 2011, Komik Kartun Karikatur, http://mbokmenik. wordpress.com/2011/11/12/komikkartun-karikatur/, (diakses pada tanggal 25 September 2012).

Geertz, H., 1983, Keluarga Jawa, terj, Hersri, Jakarta: Grafiti Press. 
Hall, S., (ed.)., 1977, Representations: Cultural Representation and Signifying Practice, London: Sage Publications. ,(eds.)., 1977, Culture the Media and the Ideological Effect, dalam J. Curran. M Gurevities dan J. Woolacott (eds.), Mass Communicatins and Society, Londong: Edward Arnold.

Jewler, A.J., dan Drewniany, B.L., 2001, Creative Strategy in Advertising, USA: Wadsworth Thomson Learning, 10 Davis Drive Belmont. Koendoro, D., 1998, Panji Koming: Kocaknya Zaman Kala Bendu, Jakarta: Penerbit Buku Kompas. 1999, "Panji Koming Kumpulan 85-86", Bandung: Penerbit Mizan.

Liliweri, A., 2003, Makna Budaya dalam Komunikasi Antarbudaya, Yogyakarta: LkiS.
Roqib, M., 2007, Harmoni dalam Budaya Jawa: Dimensi Edukasi dan Keadilan Gender, Yogyakarta: Pustaka Pelajar.

Setiawan, M.N., 2002, Menakar Panji Koming: Tafsiran Komik Karya Dwi Koendoro pada Masa Reformasi 1998, Jakarta: Kompas. ISN 979-709-011-6.

Sobur, A., 2009, Semiotika Komunikasi, Bandung: Penerbit PT. Remaja Rosdakarya.

Sugianto, J., 2010, "Peribahasa Jawa sebagai Falsafah Bangsa Indonesia", Prosiding dalam Seminar Perspektif Bahasa-Bahasa Austronesia dan Non Austronesia, Denpasar: Udayana.

Synnott, A., 1993, Tubuh Sosial: Simbolisme. Diri dan Masyarakat, terj, Pipit Maizier, Yogyakarta: Jalasutra. 